\title{
Dietary effects of drone larves homogenate on the homeostatic constants and the reproductive capacity of Large White gilts
}

\author{
Yaroslav Mykolaiovych Yemets ${ }^{1^{*}}$ \\ ${ }^{1}$ Poltava State Agrarian Academy, Poltava, Ukraine \\ yiemets21@gmail.com \\ https://orcid.org/0000-0003-0444-4066
}

*Corresponding author: Yaroslav Mykolaiovych Yemets, Poltava State Agrarian Academy, Poltava, Ukraine, yiemets21@gmail.com

\section{Abstract}

Background: With modern requirements for housing agricultural animals particularly pigs, the manifestation of normal physiological functions significantly changes, especially reproductive one, which is manifested in an insufficiently expressed sexual cycle, reduced resistance due to technological stress. There is a need to develop effective reproductive biotechnologies in pig using organic stimulants of entomological origin, among which a significant place is given to the homogenate of drone larvae (HDL). The aim of the study 
was to determine the dietary effects of HDL on the formation of prooxidant-antioxidant homeostasis in Large White (LW) gilts, as well as to optimize reproductive function during experimental feeding of HDL.

Methods: In the study, gilts representing Large White breed were investigated. A total of 20 gilts representing two groups. The first feeding group $(n=10)$ of LW gilts was fed with the control normal diet, and the second feeding group $(n=10)$ of LW gilts was fed with the supplement diet i.e., the biological additive of homogenate drone larvae in quantity of $0.5 \mathrm{~g}$ daily. To assess prooxidant-antioxidant homeostasis in pigs, blood samples were taken from the anterior vena cava into the diestrus phase i.e., 11 days from the beginning of the second cycle after the determination of the immobility reflex and the estrus phase i.e., 24 days after the start of estrus after the determination of the immobility reflex. Intracervical artificial insemination of gilts was performed during 24 and 36 hours after the determination of the immobility reflex, and depending on the manifestation of signs of estrus.

Results: Study found an intensification of peroxidation processes during the period of puberty in LW gilts, which was manifested in an increase in the content of diene conjugates on the 180th and 210 th days of development by $63.6 \%$ and $44.1 \%$, respectively. This is confirmed by a significant increase in the number of secondary products of peroxidation - TBA-active complexes in these periods of their development. Study revealed that during puberty of gilts the antioxidant defense system was the most labile from 6 to 8 months of age, where the variability of PAG components was significant in terms of increased activity of superoxide dismutase $(\mathrm{p}<0.01)$ and catalase $(\mathrm{p}<0.05)$, as well as the amount of reduced glutathione. Moreover, additional feeding of HDL contributed to the probable slowing down of peroxidation processes in blood, which was confirmed by the lower content of diene conjugates $(p<0.05-0.01)$ and TBA-active complexes $(\mathrm{p}<0.01-0.001)$.

Conclusions: Study concluded that experimental supplementary feeding of HDL diet to LW gilts stimulated the reproductive function during their puberty by reducing the time to the first estrous cycle for artificial insemination, thus improved the fertility in LW gilts.

Keywords: homeostasis; Large-White; gilts; sexual cycles; enzymes; peroxidation; homogenate of drone larvae.

\section{Introduction}

A large number of anthropogenic factors provoke chronic stress and metabolic disorders in sows, which is accompanied by a decrease in the 
manifestation of sexual cycles [1]. The use of various biologically active substances to synchronize estrus and the onset of farrowing is the best method to reduce the cost of insemination and receiving offspring. In today's conditions, the leading role in the nutrition and normalization of sexual function in pigs belongs to the use of complex biologically active additives, among which an important nutrient diet of homogenate of drone larvae (HDL), also known as drone brood homogenate (DBH) [2-4]. Previous study showed that feeding of HDL to boars alters prooxidantantioxidant homeostasis in the direction of slowing down the course of peroxidation processes, which is accompanied by an improvement in sperm quality and sperm fertility [5]. The positive effect of HDL on the body of pigs causes an increase in testicular weight, epididymis and sperm quality, as well as increasing the reproductive capacity of sows [6]. This is due to the presence of vitamins, limiting amino acids and hormones (testosterone, progesterone, prolactin, estradiol) in HDL, which do not significantly change the endocrine profile in animals [6]. It is proved that the processes of fertilization, implantation, placentation and growth and development of embryos occur with the direct participation of hormones and free radicals, the amount of which is controlled by the state of prooxidant-antioxidant homeostasis (PAG) [7-10]. Due to this leading role of active forms of oxygen in the processes of reproduction of pigs, it is important to study the features and patterns of formation of prooxidantantioxidant homeostasis in gilts, to develop ways to correct it, which can be the basis for methods to regulate their growth and development and increase reproductive function of pigs. Our study aimed to determine the dietary effects of HDL on the formation of prooxidant-antioxidant homeostasis in gilts, and to optimize reproductive function during experimental feeding of HDL.

\section{Materials and Methods}

The experiments were carried out at the Institute of Pig Breeding and Agricultural Production of NAAS. In the study, a total of 20 LW gilts 
were investigated. The experimental design was comprised of two feeding groups. The first feeding group $(n=10)$ of LW gilts was fed with the control normal diet, and the second feeding group $(n=10)$ of LW gilts was fed with the supplement diet i.e., the biological additive of homogenate drone larvae in quantity of $0.5 \mathrm{~g}$ daily. To assess prooxidant-antioxidant homeostasis in pigs, blood samples were taken from the anterior vena cava into the diestrus phase i.e., 11 days from the beginning of the second cycle after the determination of the immobility reflex and the estrus phase i.e., 24 days after the start of estrus after the determination of the immobility reflex. Intracervical artificial insemination of gilts was performed during 24 and 36 hours after the determination of the immobility reflex, and depending on the manifestation of signs of estrus [11]. The evaluation of reproductive qualities of LW gilts was performed on their fertilization, fertility, high fertility and weight of litter at birth and weaning at 28 days.

The blood samples of LW gilts were collected to determine the indexes of the state of PAG. To assess the level of peroxide oxidation, the concentration of diene conjugates - spectrophotometrically [12] and TBAactive complexes (aldehydes and ketones) photoelectrocolorimetrically [13] were determined. The level of antioxidant protection was determined by the activity of superoxide dismutase (SOD) photometrically by its ability to inhibit the oxidation of adrenaline in a biological sample. Inhibition of $50 \%$ of the rate of adrenaline autooxidation was taken as a unit of activity [14]; catalase activity (CT) according to the method using vanadium-molybdate reaction [15], the content of the reduced form of glutathione-photoelectrocolorimetrically with Elman's reagent [12]; concentration of ascorbic and dehydroascorbic acids for the number of ozones formed [13]. The resulting digital material was statistically processed using the Statistics for Windows XP. Student's T test to compare the investigated parameters and their intergroup differences, and the results were considered significant at different levels of $\mathrm{p}<0.05, \mathrm{p}<0.01$, and $\mathrm{p}<0.001$. 


\section{Results}

Feeding gilts with biologically active HDL supplement significantly inhibited peroxidation processes (Table 1). This is confirmed by the probably lower concentration of new conjugates in LW gilts of the second experimental group relative to the control on 180 th $-29.9 \%(p<0.001)$, $210^{\text {th }}-47.3 \%(\mathrm{p}<0.01)$ and $240^{\text {th }}$ day $-53.3 \%(\mathrm{p}<0.001)$. The dietary effect of this HDL additive was reduced the number of TBA-active complexes by $31.6 \%(\mathrm{p}<0.01)$ on $150^{\text {th }}, 38.8 \%$ ( $\left.\mathrm{p}<0.001\right)$ on $180^{\text {th }}, 33.3 \%$ ( $\mathrm{p}<0.001)$ on $210^{\text {th }}, 30.6 \%(\mathrm{p}<0.001)$ on $240^{\text {th }}$ and $47.5 \%$ on $270^{\text {th }}$ days of development.

It is important to note that the level of the antioxidant defense system changed significantly during puberty (Table 2 ). Thus, the activity of superoxide dismutase in the blood serum of investigated LW gilts significantly increased by $32.9 \%(\mathrm{p}<0.01)$ to the maximum values on the $180^{\text {th }}$ day of life with a subsequent decrease. The maximum functional activity of catalase $(\mathrm{p}<0.05)$ was detected when the animals reached $210^{\text {th }}$ days of age. The probable predominance of ascorbic acid content in the experimental group relative to the control group was determined as $18.0 \%(\mathrm{p}<0.001)$ on the $180^{\text {th }}$ day and $22.6 \%(\mathrm{p}<0.001)$ on the $270^{\text {th }}$ day of development. In the concentration of its oxidized form significantly increased in the first control group on the $210^{\text {th }}$ day by $14.4 \%(\mathrm{p}<0.01)$ and in the second experimental group on the $240^{\text {th }}$ by $14.8 \%(\mathrm{p}<0.001)$ and on the $210^{\text {th }}$ by $29.8 \%(\mathrm{p}<0.01)$ relative to the $120^{\text {th }}$ day of life. It should be noted that during all research periods there was a predominance of the amount of oxidized form over the reduced, where the maximum difference was found in the first group by $38.8 \%$ and the second group by $18.0 \%$. 


\begin{tabular}{|c|c|c|c|c|c|c|c|c|c|}
\hline \multirow{6}{*}{ 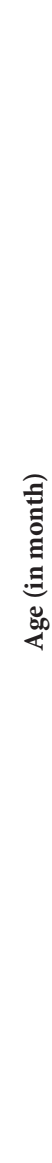 } & $a$ & $\begin{array}{l}\stackrel{n}{m} \\
\stackrel{+1}{+1} \\
\text { m. } \\
\sigma^{2}\end{array}$ & $\begin{array}{l}m \\
2 \\
0 \\
+1 \\
m \\
\stackrel{1}{N}\end{array}$ & 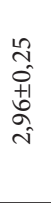 & 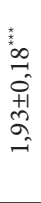 & 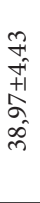 & 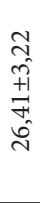 & 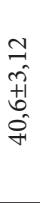 & $\begin{array}{l}\text { to } \\
\text { f } \\
m \\
+1 \\
0 \\
0 \\
0\end{array}$ \\
\hline & $\infty$ & 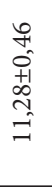 & 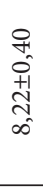 & $\begin{array}{l}\dot{8} \\
\dot{+} \\
0 \\
0 \\
0 \\
\dot{m}\end{array}$ & 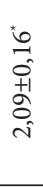 & $\begin{array}{l}\vec{m} \\
\hat{+} \\
\infty \\
m \\
\hat{m} \\
\hat{m}\end{array}$ & $\begin{array}{l} \\
\ldots \\
\hat{0} \\
0 \\
+1 \\
0 \\
0 \\
\infty \\
N\end{array}$ & 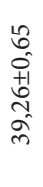 & 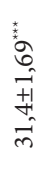 \\
\hline & $r$ & $\begin{array}{l}\stackrel{\sim}{I} \\
+1 \\
0 \\
\infty \\
\stackrel{\sim}{\rightarrow}\end{array}$ & $\begin{array}{l}\text { to } \\
-1 \\
+1 \\
0 \\
0 \\
0 \\
0\end{array}$ & $\begin{array}{l}\infty \\
\overrightarrow{0} \\
\overrightarrow{0} \\
+1 \\
m \\
m \\
m\end{array}$ & 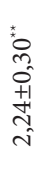 & $\begin{array}{l}\infty \\
0 \\
+1 \\
+1 \\
\hat{n} \\
\hat{0} \\
\text { की }\end{array}$ & 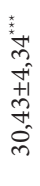 & 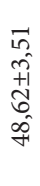 & 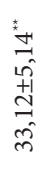 \\
\hline & 0 & 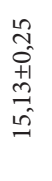 & \begin{tabular}{l}
\multirow{2}{n}{} \\
$\hat{\infty}$ \\
$\hat{0}$ \\
+1 \\
+ \\
$\hat{n}$
\end{tabular} & 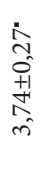 & $\begin{array}{l}\text { t. } \\
\text { N } \\
0 \\
+1 \\
\infty \\
\infty \\
\infty \\
0\end{array}$ & $\begin{array}{l}0 \\
0 \\
+1 \\
\infty \\
\infty \\
\text { bी } \\
+1\end{array}$ & $\begin{array}{l}\hat{1} \\
\hat{0} \\
0 \\
+1 \\
+ \\
\text { m } \\
m\end{array}$ & $\begin{array}{l}\hat{n} \\
\hat{n}+1 \\
\hat{n} \\
\hat{n}\end{array}$ & 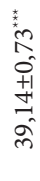 \\
\hline & in & 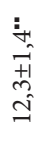 & 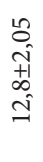 & $\begin{array}{l}\dot{0} \\
\text { m. } \\
0 \\
+1 \\
\text { 11 } \\
\text { m. } \\
\text { m. }\end{array}$ & $\begin{array}{l}\vec{n} \\
0 \\
0 \\
+1 \\
0 \\
0 \\
0\end{array}$ & 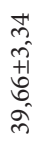 & $\begin{array}{l}\text { N } \\
\text { N } \\
+1 \\
+1 \\
0 \\
0 \\
0\end{array}$ & 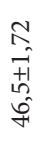 & 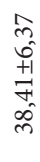 \\
\hline & + & 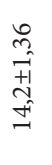 & 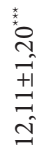 & $\begin{array}{l}\text { H } \\
\text { o } \\
+1 \\
\text { ते } \\
\text { î }\end{array}$ & $\begin{array}{l}\vec{n} \\
\hat{0} \\
+1 \\
10 \\
0 \\
-1\end{array}$ & 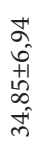 & $\begin{array}{l}\text { m. } \\
\text { ó } \\
+1 \\
\hat{m} \\
\vec{m}\end{array}$ & 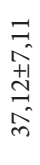 & $\begin{array}{l}n \\
10 \\
0 \\
+1 \\
\text { No } \\
\text { on }\end{array}$ \\
\hline \multicolumn{2}{|c|}{ 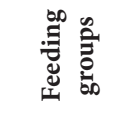 } & - & $\sim$ & - & $N$ & $\neg$ & $N$ & $\neg$ & $\sim$ \\
\hline \multicolumn{2}{|c|}{ 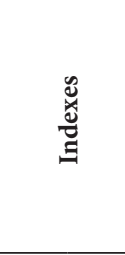 } & \multicolumn{2}{|c|}{ 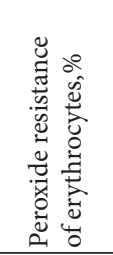 } & \multicolumn{2}{|c|}{ 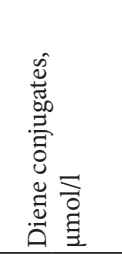 } & \multicolumn{2}{|c|}{ 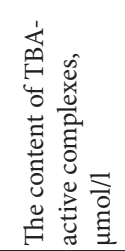 } & \multicolumn{2}{|c|}{ 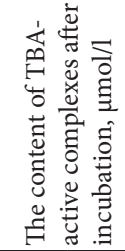 } \\
\hline
\end{tabular}




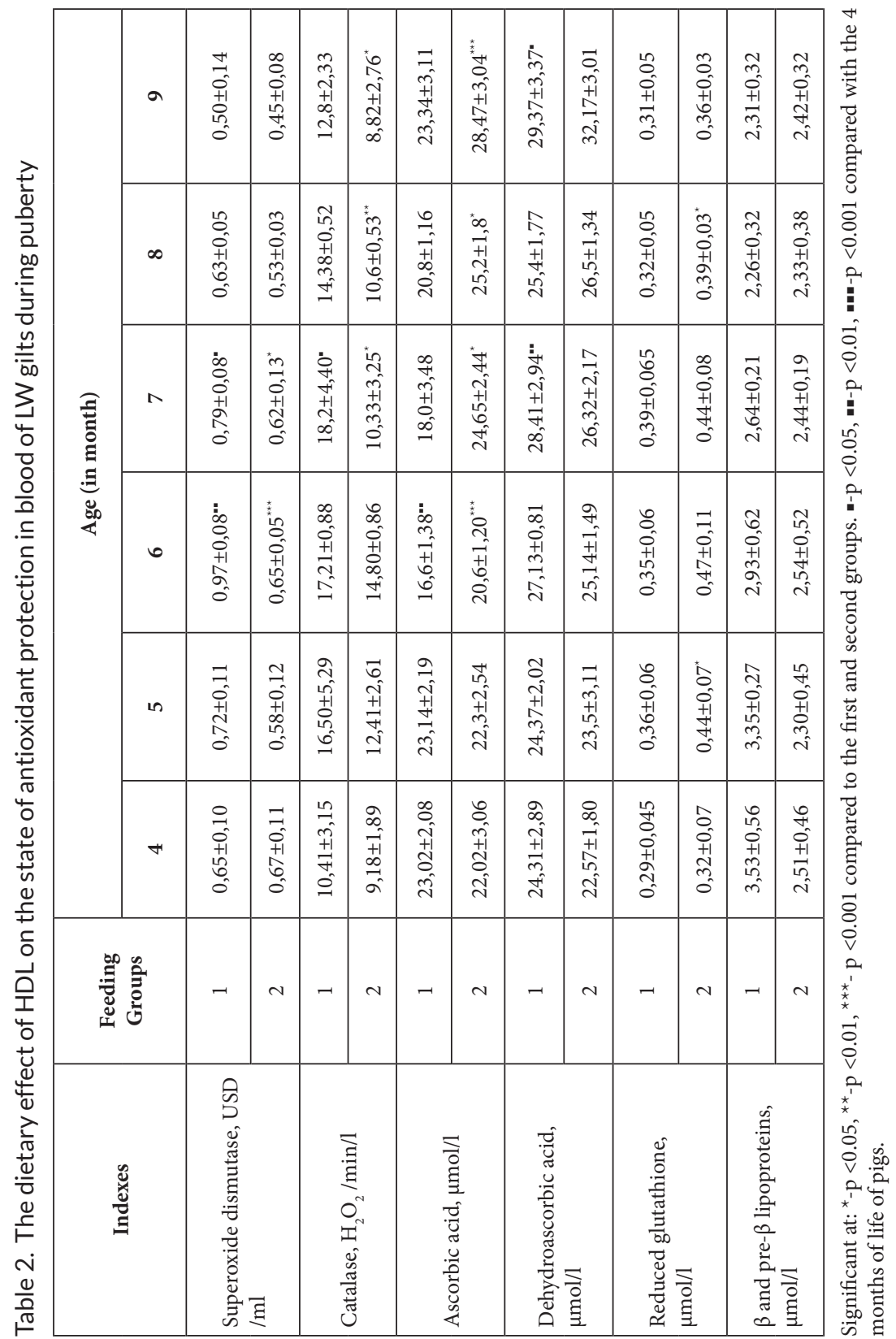


These changes in the formation of PAG during puberty significantly affected the level of peroxide resistance of erythrocytes in the direction of its growth from $240^{\text {th }}$ to $270^{\text {th }}$ days of development. However, the use of HDL in gilts increased the resistance of erythrocytes to peroxide hemolysis, especially when they reach 7 and 8 months of age, where the difference between the control and experimental groups was $25.6 \%$ $(\mathrm{p}<0.01)$ and $27.1 \%$, respectively. The content of reduced glutathione significantly increased by $18.1 \%(\mathrm{p}<0.05)$ on the $150^{\text {th }}, 25.5 \%$ on the $180^{\text {th }}$ and $11.3 \%$ on the $210^{\text {th }}$ day. Beta and pre-beta levels of lipoproteins did not change significantly during the experiment.

Results revealed that the biologically active supplement diet of HDL significantly affects the time of the first estrus, where the beginning of the first sexual cycle was set in the animals of the control group on the $162^{\text {th }}$ day, when the gilts of the experimental group had on the $158^{\text {th }}$ day of development (Table 3). A shorter duration of sexual cycles was recorded, which had 26 days from the first to the second estrus in the experimental group, while the control group had 28 days. The duration of the third cycle in the control was 23 days, the index of the experimental group was 22 days.

Table 3. Dietary effects of HDL on reproductive indexes of gilts

\begin{tabular}{|l|c|c|}
\hline \multirow{2}{*}{\multicolumn{1}{|c|}{ Reproductive indicators }} & \multicolumn{2}{c|}{ Groups } \\
\cline { 2 - 3 } & Control & Experiment \\
\hline I estrus, days & $162,0 \pm 5,09$ & $158,0 \pm 3,09$ \\
\hline Duration of the II cycle, days & $28,0 \pm 1,49$ & $26,2 \pm 1,54$ \\
\hline II estrus, days & $190,0 \pm 3,82$ & $184,0 \pm 2,26$ \\
\hline Duration of the III cycle, days & $23,0 \pm 1,69$ & $22,1 \pm 1,91$ \\
\hline III estrus, days & $213,0 \pm 2,35$ & $206,0 \pm 2,82$ \\
\hline Number of piglets at birth, ch & $12,0 \pm 0,94$ & $12,5 \pm 0,20$ \\
\hline Number of live piglets at birth, ch & $11,1 \pm 0,50$ & $11,3 \pm 0,17$ \\
\hline Large-fertility, kg & $1,3 \pm 0,10$ & $1,33 \pm 0,15$ \\
\hline
\end{tabular}




\begin{tabular}{|l|c|c|}
\hline \multirow{2}{*}{\multicolumn{1}{|c|}{ Reproductive indicators }} & \multicolumn{2}{c|}{ Groups } \\
\cline { 2 - 3 } & Control & Experiment \\
\hline Litter weight at birth, $\mathrm{kg}$ & $14,43 \pm 0,22$ & $15,03 \pm 0,14$ \\
\hline Quantity at weaning, ch & $9,44 \pm 0,09$ & $9,74 \pm 0,03$ \\
\hline Saving,\% & $85,0 \pm 1,82$ & $88,0 \pm 2,30$ \\
\hline Litter weight at weaning at 28 days, $\mathrm{kg}$ & $72,68 \pm 0,90$ & $79,18 \pm 0,68$ \\
\hline
\end{tabular}

Study found that during the rearing of the animals of the control group, the onset of the third estrus was 213 days, and in the experimental group it was accounted for 206 days of development. The difference in the formation of sexual function in these animals was apparently due to the influence of the biologically active substance HDL.

Improving the state of PAG (under the influence of feed additive HDL) in blood of gilts during puberty reduced the duration of the first and third estrus by 2.5 and 4 days, respectively, which helped to stabilize the duration of the sexual cycle. There was a tendency to improve the reproductive qualities of gilts receiving this supplement, where the number of live piglets at birth was greater by 0.2 heads, the weight of the litter at birth by $600 \mathrm{~g}$, the weight of the nest at weaning by $8.5 \mathrm{~kg}$.

\section{Discussion}

Study results revealed that additional feeding of HDL with food has a corrective effect on the endocrine and circulatory systems, resulting in increased levels of thyroxine, triiodothyronine, cortisol, resistance and reproductive capacity of animals [5]. It is proved that rearing pigs on improved complete diets enriched with biologically active components (most of which are components of HDL) provides more biologically complete offspring, significantly reducing the percentage of culling and significantly increases the efficiency of the selection process [16]. A recent 
study of Usenko [17] proved that depending on the periods of puberty of gilts and the reproductive cycle of sows, the state of prooxidantantioxidant homeostasis changes, and its changes ensure the normal course of fertilization, implantation and placentation of embryos. [17]. However, the successful implementation of these measures requires a stable function of the neurohumoral regulatory system. That is why the correction and synchronization of the reproduction function is so important.

In our study, we confirmed the significant effect of biologically active substances on the reproductive capacity of pigs, However, the leading role in the nutrition of pigs belongs to the use of complex biologically active additives, of HDL, where its action was due to the presence of vitamins $\beta$-carotene, $\alpha$ tocopherol, vitamins B1, B2, B3, B4, B5 and B6), limiting amino acids (lysine, methionine, arginine, trionine) and hormones (testosterone, progesterone, prolactin, estradiol) [18-19]. Thus, in gilts during puberty, the course of peroxidation processes changes significantly, reaching maximum values when they reach 6-8 months of age. At the same time, additional feeding of HDL significantly slows down the course of peroxidation processes, which was accompanied by an increase in the level of antioxidant protection. Changes in PAG in blood serum of LW gilts that occur when HDL included in the diet had a positive effect on their reproductive indexes, which was manifested in a reduction in the time of their economic maturity, increased fertility, and weight of piglets at weaning.

\section{Conclusions}

Study proved that during puberty of LW gilts there is an intensive increase in the content of diene conjugates in the $6^{\text {th }}$ and the $7^{\text {th }}$ months of development. This may bedue to a significant increase in the number of secondary products of peroxidation - TBA-active complexes. The dietary effects of HDL was determined that during puberty of gilts the antioxidant defense system was most responsive at 180 to 240 days of age, 
where the variability of PAG components was higher than the increased state of superoxide dismutase $(\mathrm{p}<0.01)$ and catalase $(\mathrm{p}<0.05)$ and the content of reduced glutathione. The gradual introduction of HDL into the diet significantly reduced the content of diene conjugates $(p<0.05-0.01)$ and TBA-active complexes $(\mathrm{p}<0.01-0.001)$ while inhibiting the processes of peroxidation in blood.

Study confirmed that HDL in the diet of LW gilts has a positive effect and corrects the formation of reproductive function. The formation of the first sexual cycle was accelerated, the time of manifestation of sexual cycles and the beginning of the third estrus was rationalized, the fertility of young pigs and the weight of the litter at birth and weaning increased significantly. However, subsequent studies require the development of options for control and influence on the course of gestation in sows and piglets based on the correction of their nutrition under the influence of organically formed biologically active additives.

\section{References}

[1] Blaida I.M. Obmin rechovyn v organizmi remontnykh svynok za zhodovuvannia probiotychnoi kormovoi dobavky (Body metabolism in pigs for feeding feed additives). Nauk. zhurnal Biolohiia tvaryn, 2017;19: 18-24 (in Ukrainian).

[2] Grechka GM. Vitaminnyi sklad homohenatu trutnevykh lychynok (Vitamin composition of drone larvae homogenate). Bdzhilnictvo - K. 2002;24:105107 (in Ukrainian).

[3] Cherkasova AI, Grechka GM, IO, Prohoda IO. Homohenat trutnevyh lychynok - novyi produkt bdzhilnytstva dlia vyhotovlennia apipreparativ (Homogenate of drone larvae is a new beekeeping product for the production of api preparations). Bdzhilnictvo - K. 2002;24:101-103 (in Ukrainian).

[4] Sidor E, Dżugan M. Drone Brood Homogenate as Natural Remedy for Treating Health Care Problem: A Scientific and Practical Approach. Molecules, 2020;25:5699.

[5] Kuzmenko LM, Polishchuk AA, Usenko SO, Shostya AM, Stoianovskyi VG, Karpovskyi VI, Bilash SM. Prooxidant-antioxidant homeostasis in pig uteri- 
ne tissues depending on the periods of the reproductive cycle. World of Medicine and Biology, 2018;2:198-203.

[6] Bolatovna KS, Rustenov A, Eleuqalieva N, Omirzak T, Akhanov UK. Improving Reproductive Qualities of Pigs Using the Drone Brood Homogenate. Biol Med (Aligarh) 2015;7:2.

[7] Shostya AM, Rokotyanska VO, Tsybenko VG, Sokyrko MP, Gyria VM. Osoblyvosti formuvannia prooksydantno-antyoksydantnoho homeostazu v spermalnii plazmi knuriv-plidnykiv pry zhodovuvanni nanoakvahelativ (Peculiarities of prooxidant-antioxidant homeostasis formation in sperm plasma of breeding boars during feeding of nanoaquachelates). Svynarstvo. Mizhvidomchiy tematychnyi naukovyi zbirnyk Institutu svynarstva i APV NAAN. Poltava 2018;72:93-102 (In Ukrainian).

[8] Shostya AM. Prooksydantno-antyoksydantnyi homeostaz u svynei (Prooxidant-antioxidant homeostasis in pigs). fiziolohiia liudyny i tvaryn, avtoreferat dysertatsii na zdobuttia naukovoho stupenia doktora silskohospodarskykh nauk. Lviv, 2015 (in Ukrainian).

[9] Dominguez-Perles, R, Gil-Izquierdo, A, Ferreres, F, Medina S. Update on oxidative stress and inflammation in pregnant women, unborn children (nasciturus), and newborns - Nutritional and dietary effects. Free Radic Biol Med, 2019;142:38-51.

[10] Duhig K, Chappell LC, Shennan AH. (2016) Oxidative stress in pregnancy and reproduction. Obstet Med. 2016;9:113-116.

[11] Usenko SO, Shostya AM, Polishchuk AA, Gyria VM, Rokotianska VO, Gorb OO, Voloshchuk OV, Stoianovskyi VG, Zasukha YV, Tsybenko VG., Kuzmenko LM, Stupar II. Pat. № 119099 Ukraina, MPK A 61 D 19/02. Sposib intratservikalnoho shtuchnoho osimeninnia svynok (Method of intracervical artificial insemination of gilts). zaiavnyk i patentovlasnyk Poltavska derzhavna ahrarna akademiia. - № u 2017 03185; zayav. 03.04.17; opubl. 11.09.17, Biull. № 17 (in Ukrainian).

[12] Shabunin SV. Metodicheskie polozheniya po izucheniyu processov svobodnoradikalnogo okisleniya $\mathrm{v}$ sisteme antioksidantnoy zashchity organizma (Methodical provisions on studying of processes of free radical oxidation in system of antioxidant protection of an organism). Voronezh 2010;3637;51-52 (in Russian).

[13] Rybalko VP. Suchasni metodyky doslidzhen u svynarstvi (Modern research methods in pig breeding). Poltava 2005; 114-123 (in Ukrainian). 
[14] Brusov OS, Gerasimov AM, Panchenko LF. Vliyanie prirodnykh ingibitorov radikalnykh reaktsiy na avtookislenie adrenalina (Influence of natural inhibitors of radical reactions on autooxidation of adrenaline). Bull. exp. biol. and med 1976;1:33-35 (in Russian).

[15] Korolyuk MA, Ivanova LI, Mayorova IG, Tokarev EV. Metod opredeleniya aktivnosti katalazy (Method of determining the activity of catalase). Laboratornoe delo 1988;1:16-19 (in Russian).

[16] Shostya AM, Yemets YM, Moroz OG, Stupar II., Pavlova IV., Maslak MM. Vplyv homohenatu trutnevykh lychynok na yakist spermoproduktsii u knuriv-plidnykiv. (Influence of drone larvae homogenate on sperm quality in boars). Visnik PDAA 2019;2:113-118 (in Ukrainian).

[17] Usenko SO. Osoblivosti formuvannya gomeostazu u ctsykliuiuchykh ta porosnykh svynok. (Features of homeostasis formation in cycling and pregnant pigs). Svynarstvo 2019;73:226-233 (in Ukrainian).

[18] Usenko SO, Shostya AM, Polishchuk AA, Sarnavska IV, Ribas MV, Gyria VM, Stoianovskii VG, Tsybenko VG, Zasukha YV, Voloshchuk VM. Patent na korysnu model № 118568 Ukraina, MPK (2017.01) A61D 19/00. Sposib pidvyshchennia vidtvoriuvalnoi zdatnosti svynei. (The method of increasing the reproductive capacity of pigs). Zayavnyk Poltavska derzhavna ahrarna akademiia. - № u 2017 02534; zaiavleni 20/03/2017; opubl. 10/08/2017, Biull. № 15 (in Ukrainian).

[19] Shostya AM, Yemets YM, Shaferivskyi BS, Tsybenko VG, Sokyrko MP. Vplyv homohenatu trutnevykh lichynok na prooksydantno - antyoksydantnyy homeostaz u knuriv - plidnykiv - (Influence of drone larvae homogenate on prooxidant - antioxidant homeostasis in boars). Svynarstvo 2019;73:218225 (in Ukrainian). 